\title{
Increase in bioethanol production from used office paper by Saccharomyces cerevisiae UFPEDA 1238
}

\author{
David Lima*, Ester Gouveia \\ From 5th Congress of the Brazilian Biotechnology Society (SBBIOTEC) \\ Florianópolis, Brazil. 10-14 November 2013
}

\begin{abstract}
Background
Used paper is particularly attractive as feedstock for bioethanol production because it is readily available [1]. The aim this work was to hydrolyze used office paper with dilute sulfuric acid for bioethanol production by three industrial strains of Saccharomyces cerevisiae. Acid concentration, time of the hydrolyze and ratio solid: liquid were varying according to factorial design. Reaction time was not significant. Maximum total reducing sugar content was obtained with $5 \% \mathrm{~V} / \mathrm{V}$ acid concentration and 1:10 ratio solid-liquid. Higher ethanol production was obtained by UFPEDA 1238 in $24 \mathrm{~h}$. Increase 7 to $47 \%$ was obtained in ethanol production, when S. cerevisiae UFPEDA 1238 was used in relation to other two strains.
\end{abstract}

\section{Methodology}

Used office paper of Department of Antibiotics from Federal University of Pernambuco, Brazil, was hydrolyzed with dilute sulfuric acid at $120^{\circ} \mathrm{C}$ and $1 \mathrm{~atm}$ (autoclave). The acid hydrolyzate was filtered through qualitative paper and used in the preparation of fermentation medium, after detoxification at room temperature by mixing with $\mathrm{NaOH}(4.5 \mathrm{pH})$. Acid concentration (1, 3 and $5 \%$ $\mathrm{V} / \mathrm{V})$, time of the hydrolyze (60, 90 and 120 minutes) and ratio solid:liquid (1:50, 3:50 and 1:10) were varying according to factorial design. Three industrial strains of Saccharomyces cerevisiae (UFPEDA 1238, UFPEDA 1326 e UFPEDA 1337), were used in fermentations carried out at $34{ }^{\circ} \mathrm{C}$ and $80 \mathrm{rpm}$. Samples were used for the determination of sugars, organic acids, furanic compounds and ethanol by high performance liquid chromatography on an Aminex HPX-87 $\mathrm{H}^{+}$column at $60{ }^{\circ} \mathrm{C}, 5 \mathrm{mM} \mathrm{H}_{2} \mathrm{SO}_{4}$, $0.6 \mathrm{~mL} / \mathrm{min}$ and RI-detector [2]. The total reducing sugars (TRS) content of the acid hydrolyzed were

UFPE Universidade Federal de Pernambuco, PE, Brazil measured using the 3,5-dinitrosalicylic acid reagent method [3].

\section{Results and conclusions}

Increase in acid concentration and mass of paper increased the TRS. However, the reaction time was not significant. Maximum TRS content $(28.40 \mathrm{~g} / \mathrm{L})$ was obtained with $5 \% \mathrm{~V} / \mathrm{V}$ acid concentration and 1:10 ratio solid-liquid. Starting this result hydrolyses at $10 \% \mathrm{~V} / \mathrm{V}$ acid sulfuric, with $10 \mathrm{~g}$ and $1 \mathrm{~h}$ in was carried out. Lower content of furfural and 5-hydroxymethyl furfural (HMF) were observed with $5 \% \mathrm{~V} / \mathrm{V}$ (A hydrolysate) than to $10 \%$ $\mathrm{V} / \mathrm{V}$ (B hydrolysate). In the acid hydrolyze, cellulose is hydrolyzed to glucose and hemicellulose is degraded to pentose and hexose. At high temperature and pressure, xylose and glucose are further degraded to furfural and HMF, respectively [4], which are inhibitors of the fermentation. Fermentations with A hydrolysate $(5 \% \mathrm{~V} / \mathrm{V} ; 0.9 \mathrm{M})$ were performed, using three strains of $S$. cerevisiae. Glucose was completely consumed in $24 \mathrm{~h}$. Strain UFPEDA 1326 presented higher growth. On the other hand, higher ethanol production $(1600 \mathrm{mg} / \mathrm{L})$ was obtained by UFPEDA 1238 in $24 \mathrm{~h}$. This study showed that ethanol production from used office paper is possible without the addition of cellulase enzyme.

\footnotetext{
Acknowledgements

The authors acknowledge the financial support from Conselho Nacional de Desenvolvimento Científico e Tecnológico, Brasilia DF, Brazil (CNPq).

Published: 1 October 2014

References

1. Chu KH, Feng X: Enzymatic conversion of newspaper and office paper to fermentable sugars. Process Safety and Environmental Protection 2013, 91:123-130.

2. Gouveia ER, Nascimento RT, Souto-Maior AM, Rocha GJM: Validation of methodology for the chemical characterization of sugar cane bagasse. Química Nova 2009, 32:1500-1503.
} 
3. Miller GL: Use of Dinitrosalicylic Acid Reagent for Determination of Reducing Sugar. Analytical Chemistry 1959, 3:426-428.

4. Palmqvist E, Hahn-H B: Fermentation of lignocellulosic hydrolysates II: inhibitors and mechanisms of inhibition. Bioresource Technology 2000, 74:25-33.

doi:10.1186/1753-6561-8-S4-P180

Cite this article as: Lima and Gouveia: Increase in bioethanol production from used office paper by Saccharomyces cerevisiae UFPEDA 1238. BMC Proceedings 2014 8(Suppl 4):P180.

Submit your next manuscript to BioMed Central and take full advantage of:

- Convenient online submission

- Thorough peer review

- No space constraints or color figure charges

- Immediate publication on acceptance

- Inclusion in PubMed, CAS, Scopus and Google Scholar

- Research which is freely available for redistribution

Submit your manuscript at www.biomedcentral.com/submit
C) Biomed Central 